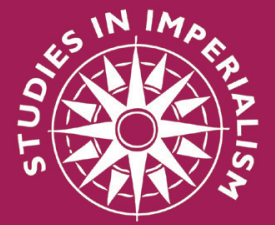 \\ MARTIAL RAGES
}

The Military, Race and Masculinity in British Imperial Culture, 1857-1914

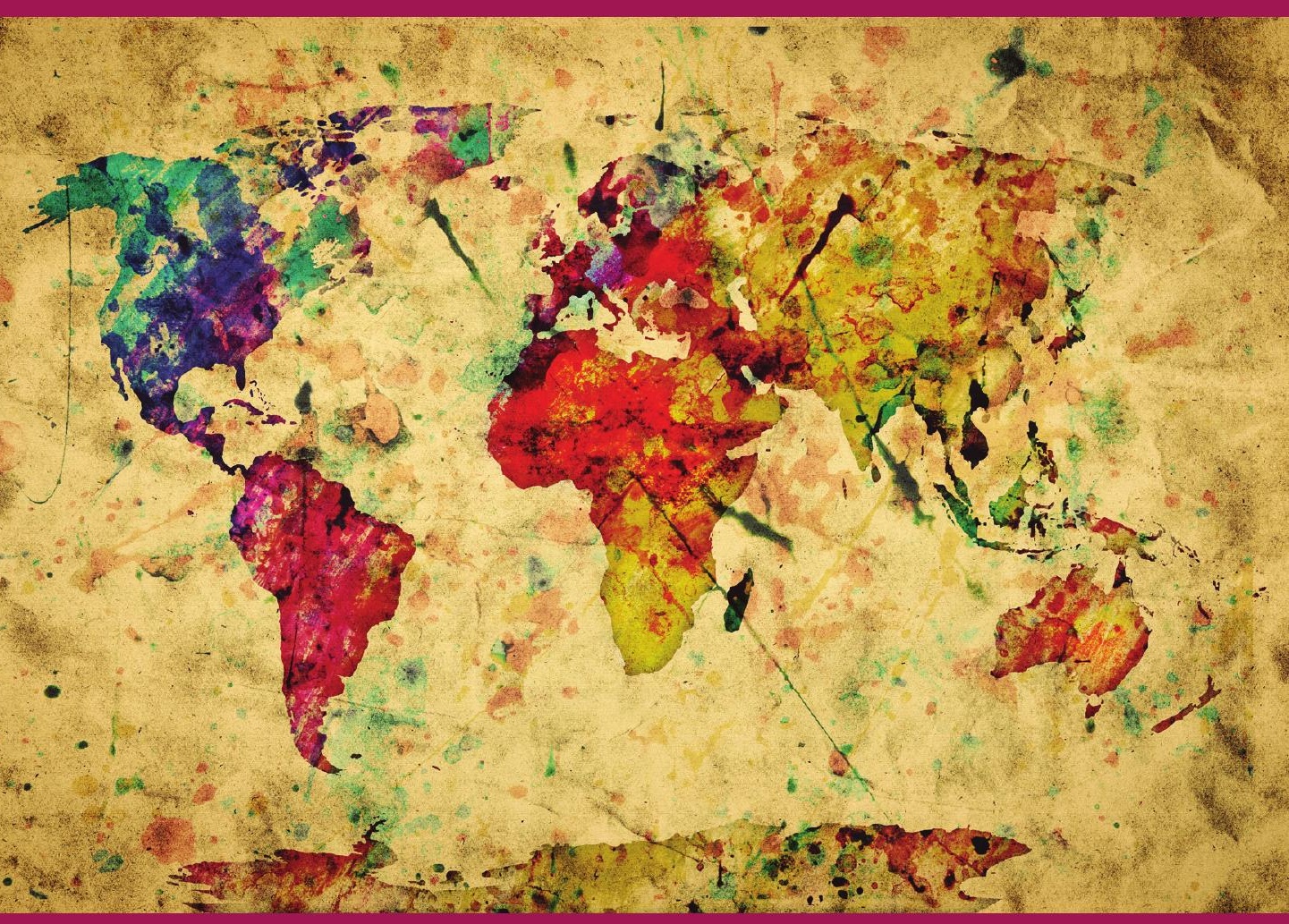

EDITED BY HEATHER STREETS 


\section{IMPERIES IN-}

general editor John M. MacKenzie

When the 'Studies in Imperialism' series was founded by Professor John M. MacKenzie more than thirty years ago, emphasis was laid upon the conviction that 'imperialism as a cultural phenomenon had as significant an effect on the dominant as on the subordinate societies'. With well over a hundred titles now published, this remains the prime concern of the series. Cross-disciplinary work has indeed appeared covering the full spectrum of cultural phenomena, as well as examining aspects of gender and sex, frontiers and law, science and the environment, language and literature, migration and patriotic societies, and much else. Moreover, the series has always wished to present comparative work on European and American imperialism, and particularly welcomes the submission of books in these areas. The fascination with imperialism, in all its aspects, shows no sign of abating, and this series will continue to lead the way in encouraging the widest possible range of studies in the field. Studies in Imperialism is fully organic in its development, always seeking to be at the cutting edge, responding to the latest interests of scholars and the needs of this ever-expanding area of scholarship.

\section{Martial races}

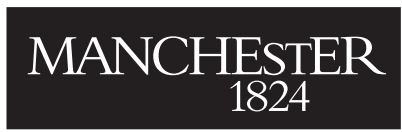

Manchester University Press 


\section{AVAILABLE IN THE SERIES}

\section{CULTURAL IDENTITIES AND THE AESTHETICS OF BRITISHNESS ed. Dana Arnold}

BRITAIN IN CHINA

Community, culture and colonialism, 1900-1949 Robert Bickers

NEW FRONTIERS

Imperialism's new communities in East Asia 1842-1952

eds Robert Bickers and Christian Henriot

THE ARCTIC IN THE BRITISH IMAGINATION 1818-1914

Robert G. David

IMPERIAL CITIES Landscape, display and identity

eds Felix Driver and David Gilbert

SCIENCE AND SOCIETY IN SOUTHERN AFRICA ed. Saul Dubow

EQUAL SUBJECTS, UNEQUAL RIGHTS

Indigenous peoples in British settler colonies, 1830s-1910

Julie Evans, Patricia Grimshaw, David Phillips and Shurlee Swain

EMIGRANT HOMECOMINGS

The return movement of emigrants, 1600-2000 Marjory Harper

EMPIRE AND SEXUALITY

The British experience Ronald Hyam

REPORTING THE RAJ

The British press in India, c. 1880-1922 Chandrika Kaul

LAW, HISTORY, COLONIALISM

The reach of empire eds Diane Kirkby and Catherine Coleborne

THE SOUTH AFRICAN WAR REAPPRAISED ed. Donal Lowry

PROPAGANDA AND EMPIRE

The manipulation of British public opinion, 1880-1960 John M. MacKenzie

THE OTHER EMPIRE

Metropolis, India and progress in the colonial imagination John Marriott GUARDIANS OF EMPIRE The armed forces of the colonial powers, c. 1700-1964 eds David Omissi and David Killingray

FEMALE IMPERIALISM AND NATIONAL IDENTITY

Imperial Order Daughters of the Empire Katie Pickles

MARRIED TO THE EMPIRE

Gender, politics and imperialism in India, 1883-1947 Mary A. Procida

IMPERIAL PERSUADERS

Images of Africa and Asia in British advertising Anandi Ramamurthy

IMPERIALISM AND MUSIC Britain 1876-1953 Jeffrey Richards

COLONIAL FRONTIERS

Indigenous-European encounters in settler societies ed. Lynette Russell

WEST INDIAN INTELLECTUALS IN BRITAIN ed. Bill Schwarz

MIGRANT RACES

Empire, identity and K. S. Ranjitsinhji Satadru Sen

THE VICTORIAN SOLDIER IN AFRICA Edward M. Spiers

BRITISH CULTURE AND THE END OF EMPIRE ed. Stuart Ward 


\title{
Martial races
}

The Military, Race and Masculinity in

British Imperial Culture, 1857-1914

\author{
Heather Streets
}




\section{Copyright $@$ Heather Streets 2004}

The right of Heather Streets to be identified as the author of this work has been asserted by her in accordance with the Copyright, Designs and Patents Act 1988 .

Published by Manchester University Press Altrincham Street, Manchester, M1 7JA, UK www.manchesteruniversitypress.co.uk

British Library Cataloguing-in-Publication Data

A catalogue record for this book is available from the British Library

Library of Congress Cataloguing-in-Publication Data

A catalog record for this book is available from the Library of Congress

ISBN 13: 9780719069635

First published 2004 by Manchester University Press

First digital paperback edition published 2010

The publisher has no responsibility for the persistence or accuracy of URLs for any external or third-party internet websites referred to in this book, and does not guarantee that any content on such websites is, or will remain, accurate or appropriate. 